\title{
To Leave, or not to Leave: That Is the Problem in A Doll's House and Candida
}

\author{
Naghmeh Varghaiyan \\ Department of Foreign Languages, Fatih Faculty of Education \\ Karadeniz Technical University (KTÜ), Trabzon 61080, Turkey \\ E-mail: nvarghiyan@ktu.edu.tr
}

Doi:10.7575/aiac.alls.v.6n.3p.118

Received: 01/02/2014

URL: http://dx.doi.org/10.7575/aiac.alls.v.6n.3p.118

Accepted: 07/04/2015

\begin{abstract}
This paper explores representation of Woman Question in Henrik Ibsen's A Doll's House and George Bernard Shaw's Candida. The paper argues that unlike many studies that have read Candida and Nora as two disparate characters, they can be considered as the same New Woman represented only from different perspectives. In the previous studies, Candida is usually labelled a philistine who chooses to stay at home in order to defend blindly the convention of marriage bond while Nora is commonly called a rebel who chooses to abandon the conventional matrimonial life in order to find her true identity. This study, nonetheless, holds that both female characters' ensuing decisions, although in different forms, similarly make their husbands reflect deeply on their situation in a way that in general the relation between them changes considerably afterwards. The female characters' socio-familial states, nevertheless, may not change considerably in the near future. Thus, the textual analysis in the present study reveals that there is no basis for establishing a dualism when discussing Candida and Nora, the former standing for conspiracy against her own gender while the latter being a symbol of female redemption. Instead, it could be argued that their seemingly different final decisions are different solutions to one problem without implying a certificate of authenticity at the end.
\end{abstract}

Keywords: Problem Play, Woman Question, New Woman, Nora, Candida

A Doll's House and Candida can be read as representation of women's situation at the end of nineteenth century Europe. At the beginning of both plays, the audience is presented a happy family on the verge of losing its stability and at the end of them they take in a family in which the already existing values are no longer at work. Instead, they are redefined. Between the two ends in both plays, the audience can trace the argument related to woman. Thus, the present paper aims, at first place, to explore A Doll's House and Candida as problem plays referring to Woman Question both in their authors' time and within the plays.

It is believed that any outstanding social, moral, political, economic and the other human-related problems can be reflected in a problem play. Its aims are to question and analyse the existent ideas, conventions, customs, and firmlyheld religious, social and moral values in order to bear upon the state of these affairs in society. In other words, with problem play, "drama became a direct criticism of life" (Sodhi 66). Moreover, "this kind of drama," according to Marjorie Boulton's discussion in her Anatomy of Drama (1960), "became popular in the late nineteenth and twentieth centuries. But we can place the early classical plays like Antigone and Electra under this category. Some of Shakespearean plays, for example Measure for Measure, Hamlet, are considered to be problem plays" (in Sodhi 66). This kind of play, however, was first popularized by Henrik Ibsen (Abrams 171 and Sodhi 61) and then flourished in the works of George Bernard Shaw. The two authors are mainly believed to represent the social and moral problems in their plays with(out) providing solutions at the end. In other words, as Ochshorn says, they "subverted established beliefs through direct handling of political themes in their dramas. Shaw saw in Ibsen a revolt against the values of his era, the materialism and hypocrisy of the nineteenth century" (102). Moreover, their aims were to make people, as Sodhi argues, "think intelligently" and be aware of the "social plights" existing among themselves by choosing the real problems of life "as the normal material of drama" (67-69). Although Ibsen, "who sought to make the drama as a vehicle for responsible discussion of modern problems", did not inaugurate this kind of play, his A Doll's House "set the trends for popularizing this drama [problem play]" (Sodhi 66-67). Moreover, Ramsden Balmforth analyses the social and economic problems illustrated by the dramas of Ibsen, Tolstoy, Shaw, and Galsworthy. Referring to Ibsen, Balmforth reminds us that he is an "individualist because he felt that the individual's right to the development of his personality was more important than the rights of society or of the state, and especially the State as then organized" (25). Likewise, the desire for the development of the individual state seems to be the main powerful force that stimulates both Candida and Nora in their rebels.

The question whether both Ibsen and Shaw wrote problem plays or not is under debate. Contrary to many other critics, Martin Lamm, the author of Modern Drama (1952), argues that "both Shaw and Ibsen wrote problem plays in which they expound their ideas" (in Gerould 132). Considering Shaw, there is no doubt that for him "drama was more than a genre through which he tried to change the sham ideas of society" (Jain 18). As a "socialist in search of political and 
artistic answers" (Ochshorn 102) and as a member of British Fabian Society, Shaw considered his artistic mission to propagate his political and social ideas in his works. In other words, "he was a political artist, a social writer" (Williams 244). From this perspective, Ibsen is unlike Shaw. According to Sangeeta Jain, he was not a self-expressed "socialist", "moralist", or "didactic" (14). Whatever he tried to reflect in his drama was for the improvement of "human condition" regardless of sex. However, it is believed that League of the Youth (1869), Pillars of Society (1978), A Doll's House (1879), Ghosts (1882), and Enemy of the People (1882) "were Ibsen's main contribution towards the growth of the "problem play" in England. The subject matter of these plays presented a very realistic criticism of society" (Jain 14). Therefore, some of Ibsen's plays can be read as social plays in which the problems of human condition are reflected.

It is universally acknowledged that Shaw was "electrified by Ibsen, coining the word 'Inbsenism"” (Ochshorn 96). In his article "George Bernard Shaw's Criticism of Ibsen", Daniel Charles Gerould argues that Shaw was the first critic "who became self-appointed exponent of Ibsen's message to the British public" (130). However, nearly all critical statements in his Quintessence of Ibsenism (1891, revised edition in 1913), together with his other writings on Ibsen have "been almost uniformly unfavorable" (Gerould 130). Shaw calls Ibsen a "social prophet", a "social reformer", and his drama full of "social problem" issues (in Gerould 131-45). Such an interpretation of Ibsen, however, has ever been considered as a "misguided Ibsen criticism" by critics (Williams 244 and Gerould 130-32). Among the others, critics such as Archer, James Huneker, Miriam A. Franc, Ronal Peacock, Edmund Wilson and Eric Bentley believe that Shaw "misinterpreted" Ibsen by ignoring the poetic side of his works because "the non-poet is incapable of understanding Ibsen the poet"(Gerould 131). While Williams acknowledges that Shaw "misinterpreted" and "misrepresented" Ibsen, he still states that Shaw's seminal work on Ibsen "was one of the forces which produced in England what was known as the "New Drama"' (Williams 244). Regardless of the critical responses to Shaw's works on Ibsen, it was Shaw who firstly introducy Ibsen. Making him famous in England, he presented his work as an imitable style among the dramatists. Shaw's interest in Ibsen, however, was not pointless since, pursuing different ways, they both deconstructed and reconstructed the traditional dramatic conventions.

The social status of women prior to the onset of twentieth century was not satisfactory. At that time,the majority of middle class women found themselves without any help, financial support and belongings. The scope of a woman's life and duties was then under hot debates, especially during the second half of the nineteenth century. This state is noticeable from the literary works written by Mary Wollstonecraft, Sojourner Truth, Lydia Chapin, Susan B. Anthony, John Stuart Mill, Stephen Leacock et cetera. It also lies behind such social movements as nineteenth century Women Suffrage Movement, the Married Women's Property Act and Equal Rights Amendment (ERA). In the Victorian realm of understanding, an ideal woman was considered as the angel in the house, being at the service of his father, husband, and children. Being supported by religious, moral and legal principles, these duties were considered sacred and holy. The traditional conventions about women, however went under hot debates during the last decades of the nineteenth century. There was a revolutionary change in women's needs as "both in England and America the nineteenth century saw unprecedented changes in the conditions of women's lives. [...] Battling for the vote, demanding the right to own property and retain custody of their children after divorce etc." (Gilbert and Gubar 407). Likely, Nora and Candida are, unexpectedly, challenging the conditions of their lives.

The Woman Question, as highlighted by critics, is a direct theme in Shaw and an indirect theme in Ibsen. In other words, Shaw knowingly penned for the rights of women. In addition, his women characters were from a new generation of women. Nevertheless, although the female issues is a repeating theme in Ibsen's plays, he was not a declared feminist. Despite that, as Ochshorn holds, Shaw generally "cast Ibsen as feminist and radical, in his own image- the anti-idealist" (98). Likewise, according to Jain, Ibsen "was an unconscious, unassuming pioneer of feminist cause. Although Ibsen never envisaged himself as a champion of woman's rights yet intentionally or unintentionally he strongly supported woman's cause in his plays as well as in his personal life" (Jain 22). In a speech given to the Norwegian Women's Right League in 1898, Ibsen insisted that he "must disclaim the honor of having consciously worked for women's' rights movement. [...] True enough, it is desirable to solve the woman problem, along with all the others; but that has not been the whole purpose. My task has been the description of humanity" (in Templeton 110). However, Ibsen's relationship to the Woman Question "has been a vexed one. The view supporting Ibsen as a feminist can be seen to lie along a spectrum of attitudes with Ibsen as quasi-socialist at one end and Ibsen as humanist at the other" (Finney 89). If Ibsen, as it is argued, questioned the conventional values about women under the pretext of humanism, Shaw did so under the pretext of his support for individual will. In other words, "The concept of 'New Woman' was poularised with the advent of George Bernard shaw who subverted the conventional views on every aspect of the society" (Jain 1). The concept of New Woman, according to Jain, is closer to the modern concept of woman who "unlike conventional Victorian woman, was not accustomed to self sacrifice; she chose her career for a living and pursued self fulfillment and independence. She strove for equality in her relationships with men, discarding the double standards of sexual mores of the time" (22). Thus, the Woman Question was an underlying theme in both Ibsen - influenced by the Norwegian pioneers of the feminist movements (Jain 23-24) — and Shaw who considered it as his artistic mission to improve the condition of mankind, regardless of man or woman. Moreover, marriage and the condition of a woman in matrimonial life, referred to as Woman Question, is a significant motif in both A Doll's House and Candida. Nora, the protagonist of the first play, is a New Woman who longes for self knowledge and individuality and Candida. Likewise, the protagonist of the second play is a New Woman whose decision making ability is a sign of her longing for self assurance and independence. 
Nora abandons her husband and children at the end of $A$ Doll's House. Her unexpected decision is usually interpreted both as a sign of awakening for women and as an appearance of New Woman who is no longer tolerant of a husband all dominance and demanding. When A Doll's House appeared in London's scenes, its woman-problem related theme circulated in the critical society (Egan 101-125). Fredric Wedmore, for example, argued that it is "a drama written partly to show that in a life of civilization a woman must not be considered as man's creature alone-a ministrant or toy" (in Egan 107). Spectator in An Unsigned Notice reflected that "Ibsen's play [...] is a rather high-flown attempt to make men realize how grave a wrong it is to women to treat them as if they were mere toys made for men's pleasure, rather than for companionship in study, duty, and responsibility" (in Egan 110). The play's performance, also, incited Shaw's reflection in which he approvingly stated that:

The play solves the problem (awakening of the woman) just as it is being solved in real life. The woman's eyes are opened; and instantly her doll's dress thrown off and her husband left staring at her, helpless, bound henceforth either to do without her ... or else treat her as a human being like himself, fully recognizing that he is not a creature of one superior species, Man, living with a creature of another and inferior specie, Woman, but that mankind is male and female. (Egan 376)

Nora in her past eight years of living with Torvald Helmer has had three children, worked and saved to support family when it needed. She even borrowed - though illegally and by forging her father's signature of commitment to repay the money-from Krogstad to save Helmer's life, when he was sick, without his own knowledge. Nora pretended to Helmer that she borrowed the money from her father. She has kept "this unhappy secret" for a long time in order not to hurt Helmer: "how painful and humiliating it would be for Torvald, with his manly independence, to know that he owed me anything!" (Ibsen 13) Helmer has always admired Nora by calling her pleasantly_my little lark, my squirrel, my little skylark, my little song bird, my obstinate little woman, my precious little singing bird et cetera. Daspite that, when it comes to such matters as manly independence, he does not come short. The family disintegration begins when Helmer is promoted to the manager of a bank where Krogstad, being accused of forgery, is on the verge of losing his low-level position. Krogstad knows Nora's forgery of her now-dead father's signature and is going to use it as a pretext to have Nora put force on her husband in order to keep him in the bank. Nora, therefore, is misused not just by Krogstad but by her father and husband too- or by patriarchal society. She did not dare to ask money from her father since she thought he would not give; she did not also dare to let her husband know the fact about the money borrowed because her husband would get infuriated taking it as an insult to his manly independence. In order to disclose everything related to the borrowed money from Krogstad and her own forgery to Helmer, Noral is forced, on the one hand, by Krogstad's pressure and, on the other hand, by that of Mrs Linde's - her close friend who believes that "this unhappy secret must be disclosed" (Ibsen 52). Calling all Nora's words "silly excuse", Helmer gets infuriated: "what a horrible awakening! All these eight years- she who was my joy and pride-a hypocrite, a liar- worse, worse- a criminal! The unutterable ugliness of it all! For shame! For shame! [...] No religion, no morality, no sense of duty" (Ibsen 60). It is after Helmer's initial infuriated reaction that the most authentic part of the play begins, as John Gassner says in the introduction to Sharp's translation of Four Great Plays by Henrik Ibsen, "the most original part of the play was the discussion Nora initiated once the threat of prosecution for forgery was completely removed by the blackmailer's repentance" (1). Helmer's immature reaction brings Nora to a new understanding - unknown to her until then - that she should take herself out of her husband's care, as she says "I am beginning to understand" (59). This moment of understanding is the turning point in the play whose last ten pages can be read as a review of the Woman Question, as represented by that of Nora, at that time and future too. Nora is willing to take herself out of Helmer's care. She is aware of the power of education: "I must try to educate myself-you are not the man to help me in that. I must do that for myself. And that is what I am going to leave you now" (Ibsen 64). In her recollections of the past, Nora finds out she has always been owned and governed by somebody who misunderstood and abused her: "you have never understood me. I have been greatly wronged, Torvald-first by papa then by you" (Ibsen 63). She leaves because she thinks that she deserves an equal respect:

Helmer: I would gladly work night and day for you, Nora-bear sorrow and want for your sake. But no man would sacrifice his honor for the one he loves.

Nora: It is a thing hundreds of thousands of women have done. (Ibsen 63)

The New Woman, therefore, does no longer accept the limitation of honor to men; in contrast, it is implied that she yearns for equality between both genders. It is mainly for this reason that Nora, at last, decides to leave Helmer. Shaw was right when he said "it is clear that Helmer is brought to his senses and that Nora's departure is no claptrap 'farewell forever,' but a journey in search of self-respect and apprenticeship to life. [...] The slam of the door behind her is more momentous. [...] There is an end of the old order" (Egan 376).

In the same way, Candida's decision in Shaw's eponymous play Candida can be considered as a sign of independence and self assurance that the conventional woman lacked. Candida is a play about love and marriage in a middle class family besides being about many other issues including socialism and class relations. Being a charming woman, Candida is adored and loved by both her husband parson Reverend James Mavor Morell—a Christian socialist and a charismatic preacher - and a young poet Eugene Marchbanks although she "is impressed by neither; she trivializes the effects of Morell's oratory, attributing his rhetorical effectiveness to his sex appeal, and Eugene's verses bore her. She would rather he reverted to his usual conversational 'moonshine"' (Luckhurst 70). The image of Morell and Candida's 
seemingly happy marriage shatters when Eugene Marchbanks, a young poet brought home by Morell out of compassion, enters into their relationship and declares his love for Candida. Nevertheless, his love is not a pure love too; instead, as Margery Morgan says, "it is a blend of erotic with religious emotion" (in Luckhurst 72). In the last part of the play, Candida is offered a choice between the two men and she chooses "the weaker" who comes out to be her husband too. Morell is a typical man of Helmer type who believes in a sacred concept of marriage in which man is provider/owner and woman is merely a follower who needs 'care'. When Morell is teased by Eugene, who claims that Candida will prefer him at last, he cries out: "if she is mad enough to leave me for you, who will protect her? Who will help her? Who will work for her? Who will be father for her children?" (Shaw 1308) Morell's understanding of marriage derives from his theology. To him, marriage is a "foretaste of what will be best in the kingdom of Heaven we are trying to establish on earth" (Shaw 1272) whereas Candida's understanding of marriage is humanitarian. The two unlike perspectives of the same concept ends at Candida's dissatisfaction with her matrimonial life, as she says: "Ah, James, how little you understand me. [...] You understand nothing” (Ibid). She craves for co-understanding, as Nora did, although she seemingly wins at last. It seems that she has become a New Woman because she:

is independent in spirit, has confidence, is courageous, and has emotional stability. She is guided more by common sense and does not allow men to quarrel over her; on the contrary she imposes her will on them. The auction scene, at the end of the play is a determined declaration of independence quite as definite as the slamming of the door in Ibsen's A Doll's House. (Sodhi 69)

Candida's determining change happens the moment she finds herself in what she calls an auction. This moving recognition brings about her ironic reaction: "Pray, my lords and masters, what have you to offer for my choice? I am up for auction, it seems. What do you bid, James?" (Shaw 1314) Morell, however, offers her the conventional items a man offered at that time: "I have nothing to offer but my strength for your defense, my honesty for your surety, my ability and industry for your livelihood, and my authority and position for your dignity. That is all it becomes a man to offer a woman" (Shaw 1315).

In A Doll's House, moreover, Nora basically abandons Helmer in order to find out whatever Morell is offering Candida: defense, surety, livelihood, and dignity. Both of them are pursuing these items after their awakening. Unlike Nora, Candida is able to use her charm in order to have Morell understand that it is in fact he who needs care. Finally, Morell acknowledges it too: "It's all true, every word. What I am you have made me with the labor of your hands and the love of your heart! You are my wife, my mother, my sisters: you are the sum of all loving care to me. You are my wife, my mother, my sisters: you are the sum of all loving care to me." She blames her own sex, as she does blame the opposite one, for bringing about the existing condition: "I build a castle of comfort and indulgence for him [...] I make him master here" (Shaw 1316). Compared to Nora, as H.C. Duffin in The Quintessence of Bernard Shaw states, Candida is however considered "a Shavian intellectual woman, full-fledged, not an Ibsenite womanly woman on the point of being reborn" (in Nethercot 2). Moreover, Nethercot in his article, "The Truth about Candida" (1949), calls Candida a philistine, Morell an idealist and Marchbanks a realist alluding to Shaw's differentiation of the terms in his The Quintessence of Ibsenism:

Philistines are those who "find the British family arrangement quite good enough for them"; they "comfortably accept marriage as a matter of course," never dreaming of calling it an "institution," either "holy" or otherwise, and thrive happily within it. The idealists realize that marriage, for plenty of those involved in it, is a failure, but do not have the courage to face that fact, and therefore go to all sorts of excessive ex-tremes to defend what Shaw calls the "ideal" which for them masks the face of the truth. The lonesome realist is the individual "strong enough to face the truth the idealists are shirking"-the man who insists on tearing off the masks and revealing the illusions beneath. (4)

To support his idea of calling Candida a philistine, Nethercot continues his argument by citing Prossy's statement at the beginning of the play:

PROSERPINE (rising busily and coming to the stationery case to get an envelope, in which she encloses the letter as she speaks) Candida here, and Candida there, and Candida everywhere! (She licks the envelope.) It's enough to drive anyone out of their SENSES (thumping the envelope to make it stick) to hear a perfectly commonplace woman raved about in that absurd manner merely because she's got good hair, and a tolerable figure. (Shaw 1272)

However, according to the overall discussion in Candida, the attribution of philistine to Candida-based on a character's statement-does not seem to be totally convincing. What is more considerable about Candida's characterization is the fact that she is not primarily using her beauty for any personal abuse, as it is implied in Nethercot's statement, but rather to instigate her husband to admit and respect her rights. Morell offers her whatever every woman needs. Thus, it can be noted that her defense of marriage is more than duping herself. 
Candida, therefore, can be read as a play about a woman's proclamation of her individuality, the same subject that Nora, at the end of $A$ Doll's House, slams the door for-individual freedom. Accordingly, it appears possible to argue that self-recognition is a shared theme that mainly matters in both plays. However, although Candida was not received as revolutionary as Ibsen's play or it did not ignite as much criticism as A Doll's House, they resemble each other in highlighting the concept of woman as understood by men or patriarchal mentality. Like $A$ Doll's House, Candida brings forth some questions about marriage as it was then conceived. Likewise, as Sodhi put, "in Candida Shaw makes the wife settle the dispute by imposing her will upon the two men in her life. The story discusses the issues related with love and marriage rationally and intellectually" (68). Moreover, according to Barrett H. Clark, "Candida is a shaft aimed at current conceptions of what is moral, right, and fitting [...] in Candida Shaw attempts to shatter the ideals of the "sanctity of the family" (in Hinchliffe 162). True that it is restrictive to interpret both plays only from this perspective, this approach, however, is one of the possible readings that has attracted many critics' attention. At the end of the plays, the two heroines definitely come to a decision which can be read as representation of their struggle for recognition - such assurance and endeavor of a woman at the end of nineteenth century can be taken as a victory for the women movement. Thus, it is no longer important whether Ibsen or Shaw supported the women freedom movement, what seems significant is that they, as artists, were supporters of human kind, regardless of male or female, and for its improvement alone they created such an atmosphere in their drama.

\section{References}

Abrams, M.H. A Glossary of Literary Terms. (6 ${ }^{\text {th }}$ ed.). New York: Harcourt Brace \& Company, 1993. Print.

Balmforth, Ramsden. The Problem-Play and Its Influence on Modern Thought and Life. New York: Haskell House

Publishers Ltd, 1997. Print.

Egan, Michael. Ed. Henrik Ibsen: the critical Heritage. London and New York: Routledge, 1997. Print.

Finney, Gail. "Ibsen and Feminism." The Cambridge Companion to Ibsen. Ed. James McFarlane. Cambridge: Cambridge University Press, 1994: 89-105. Print.

Gerould, Daniel Charles. “George Bernard Shaw's Criticism of Ibsen.” Comparative Literature, 15.2 (1994): $130-145$. Web. 2 July, 2012.

Gilbert, Sandra M. and Susan Gubar. Eds. The Norton Anthology of Literature by Women. New York and London: W.W. Norton \& Company, 2007, Print.

Hinchliffe, Arnold P. Ed. Drama Criticism Developments since Ibsen. London: The Macmillan Press Ltd, 1979. Print. Ibsen, Henrik. Four Great Plays by Henrik Ibsen. Trans. R. Farquharson Sharp. New York: Bantam Books, 1981. Print. Jain, Sangeeta. Women in the Plays of George Bernard Shaw. New Delhi: Discovery Publishing House, 2006. Print. Luckhurst, Mary. Ed. A Companion to Modern British and Irish Drama 1880-2005. Oxford, Blackwell, 2006. Print. Nethercot, Arthur H. "the Truth about Candida.” PMLA, 64.4 (1949): 639-647. Web. 7 July, 2012.

Ochshorn, Kathleen. “Who's Modern Now? Shaw, Joyce and Ibsen's When We Dead Awaken." SHAW: The Annual of Bernard Shaw Studies, 25.1 (2005): 96-104. Web. 08 April, 2015.

Shaw, George Bernard. "Candida." Drama: the Elements of Drama. Ed. Laurence Perrine. New York: Southern Methodist University, 1980. Print.

Sodhi, Meena. Shaw's “Candida”: A Critical Introduction (Atlantic Critical Introductions to Literature). New Delhi: Atlantic Publishers and Distributers, 1995. Print.

Templeton, Joan. Ibsen's Women. Cambridge: Cambridge University press, 1997. Print.

Williams, Raymond. Drama from Ibsen to Eliot. London: Chatto \& Windus, 1952. Print. 